\title{
Comparative study of breakwater crown wall - calculation methods
}

1 Vicente Negro Valdecantos DCivEng Associate Professor, Technical University of Madrid, Madrid, Spain

2 José Santos López Gutiérrez DCivEng Assistant Professor, Technical University of Madrid, Madrid, Spain
3 Jose Ignacio Polvorinos Flors

Doctoral student, Technical University of Madrid, Madrid, Spain
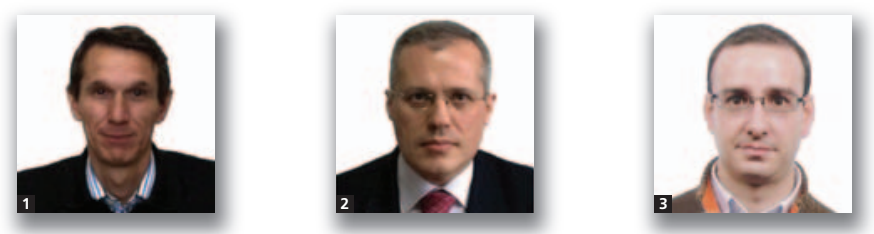

An investigation was undertaken consisting of a state-of-the-art and comparative analysis of currently available methods for calculating the structural stability of wave walls in sloping breakwaters. A total of six design schemes are addressed. The conditions under which the formulations and ranges of validity are explicitly indicated by their authors, are given. The lack of definition in parameters to be used and aspects not taken into account in their investigations are discussed and the results of this analysis are given in a final table. An investigation proposal based on an energy approach, in which the transmission of waves incident on the porous medium and its effect on the wall face is studied, brings the discussion to its close.

\section{Notation}

$B_{\mathrm{u}}$

F

$h$

$h_{\mathrm{f}}$

$p_{\mathrm{H}}$

$P_{\text {ra }}$

$P_{\text {re }}$

$P_{\text {So }}$

So

$V_{\mathrm{h}}$

$W L$ $\mathrm{Z}$ coefficient for calculating run-up width of the crown wall foundation half the wave height, wave height $=2 h$ height of wave wall uniform horizontal pressure uplift pressure at the front of the crown wall foundation

uplift pressure at the extrados of the crown wall foundation

dynamic pressure

width of the sheet of water ascending on the slope at level $A_{\mathrm{c}}$

maximum horizontal velocity of the crest wave

water level of the experimental set-up vertical coordinate, positive in an ascending direction (origin is at the design sea level)

\section{Introduction}

The wave wall has been a usual element in offshore works for decades, due to its great usefulness, especially in sloping breakwaters. It enables the elements in the armour layer to be reduced, reduces the possibility of the breakwater being overtopped and, therefore, it improves the operability of the quays it protects, provides an access that may be used for maintenance work and the possibility of bringing in service systems. Installing a gallery from which to monitor the status and behaviour of the breakwater inside the wave wall started in recent decades.

Wave study has noticeably evolved with the passing of time. Statistical geometry and the evolution of recorders and measuring and prediction systems have brought advances in spectral analysis and consideration of wave energy, including the application of energy balances and effects of transmission and dissipation. Formulations available to determine the forces that waves produce on sloping breakwater wave walls do not explicitly embody these new energy criteria.

The aim of this study was to analyse and compare existing wave wall calculation methods, determining their ranges of application and detecting their uncertainties. This has led to a reflection on and proposal for new lines of investigation enabling the energy transmitted by waves onto the protection berm to be embodied.

Wave wall failure modes are

- sliding over foundations 
Comparative study of

breakwater crown wall -

calculation methods

Negro Valdecantos, López

Gutiérrez and Polvorinos Flors

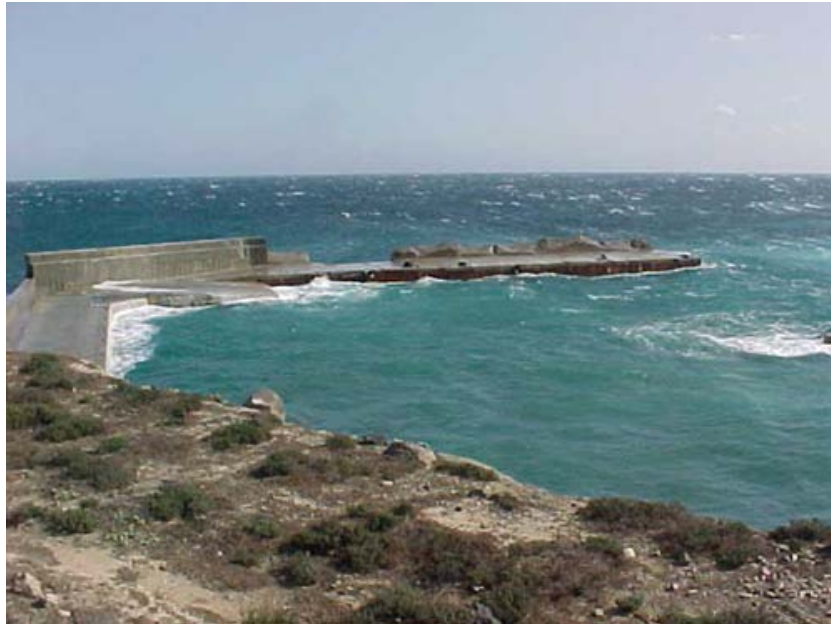

Figure 1. Port of the island of Alborán (southern Spain). Hammer shock failure in 2001

- overturning from wave action

- overturning from foot undermining

- foundation plasticisation

- point failure through hammer shock.

This paper addresses the first two modes of failure. Photographs of recent failures are shown in Figures 1 to 3 .

\section{State of the art}

Six methods for wave wall calculation are currently available. The notation used by the authors themselves in their respective papers has been retained and is defined in the text following the equations associated with each method.



Figure 2. Port of Motril, Granada (southern Spain). Slide failure in 2004

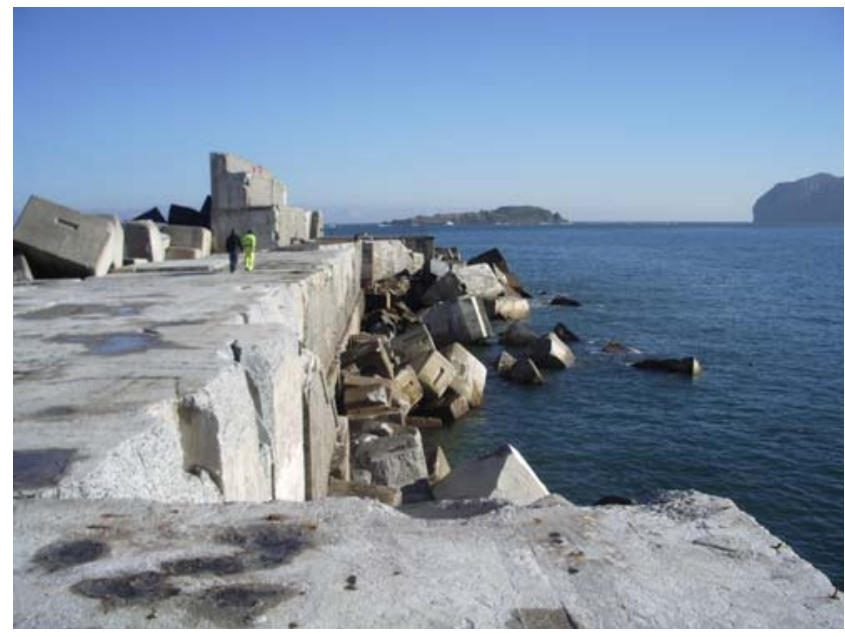

Figure 3. Port of Bermeo, Biscay (northern Spain). Slide failure and overturning in 2010

Three give pressures as a result (Iribarren and Nogales, Günbak and Göcke, Martín et al.) and the other three give forces (Bradbury and Allsop, Pedersen and Burcharth, Berenguer and Baonza). Each one is briefly addressed herein; they are grouped by the type of result they obtain (forces or pressures).

\subsection{Pressure diagrams}

\subsubsection{Iribarren and Nogales (1954)}

Iribarren and Nogales (1954) were the first to define the forces waves exert on the wave wall. Their work provides a pressure diagram as shown in Figure 4.

The representative height of the pressure at the crest is

1. $\mathrm{EB}=2 \frac{V_{\mathrm{h}}^{2}}{2 \mathrm{~g}}=h$

The representative height of the pressure at the trough is

2. $\mathrm{JC}=2 \frac{V^{2}}{2 g}=5 h$

The presence of rock fill reduces the pressure to half and the pressure law on the wave wall is defined by ABD (see Figure 4). The definitive law of pressures exerted by the wave would be the line $\mathrm{ABH}$ in Figure 4. It considers that the friction between the base of the wave wall and the foundation is $0 \cdot 50$.

\subsubsection{Günbak and Göcke (1984)}

The model proposed by Günbak and Göcke (1984) assumes a uniform pressure distribution at the wave wall's freeboard 


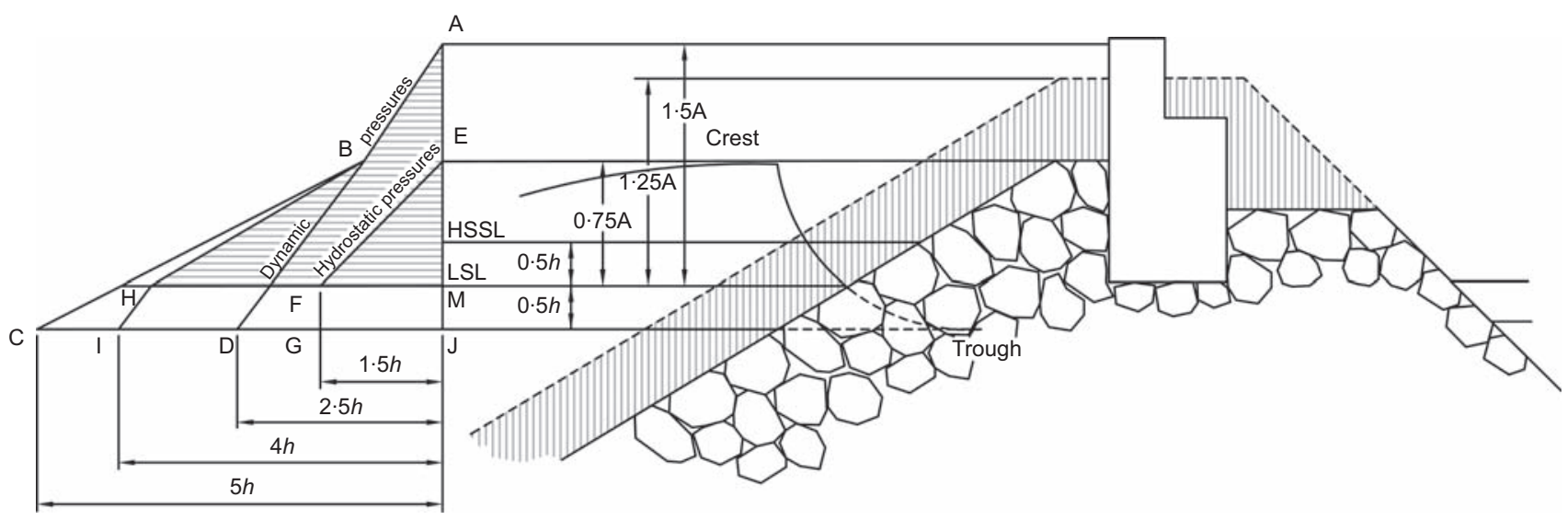

Figure 4. Pressure distribution according to Iribarren and Nogales; HSSL, high still sea level; LSL, low sea level; wave height $=2 h$. Source: Negro et al. (2008)

which is called shock pressure $\left(P_{\mathrm{m}}\right)$. This figure is linearly reduced until reaching $50 \%$ at the base of the wave wall because of the presence of the protective layer. To this pressure is added the hydrostatic pressure $\left(P_{\mathrm{h}}\right)$ corresponding to run-up. The uplift pressure at the wave wall's base is triangular, as shown in Figure 5.

3. $P_{\mathrm{m}}=\frac{\gamma_{\mathrm{w}}(\sqrt{\boldsymbol{g} y})^{2}}{2 \boldsymbol{g}}=\frac{\gamma_{\mathrm{w}}}{2} y \quad$ (shock pressure)

4. $P_{\mathrm{h}}=\gamma_{\mathrm{w}}(y+s) \quad$ (hydrostatic pressure)

5. $y=\frac{\left(R_{\mathrm{u}}-A_{\mathrm{c}}\right)}{\sin \alpha} \frac{\sin \beta}{\cos (\alpha-\beta)}$

The run-up is calculated with Günbak's formulation (Günbak and Göcke, 1984), according to which

6. $\quad R_{\mathrm{u}}=0 \cdot 4 \xi H \quad$ if $\xi<2 \cdot 5 \quad$ with $\xi=\sqrt{\frac{\boldsymbol{g}}{2 \pi H}} T \tan \alpha$

7. $R_{\mathrm{u}}=H$ if $\xi>2.5$ with $\xi=\sqrt{\frac{g}{2 \pi H}} T \tan \alpha$

where $A_{\mathrm{c}}$ is the height of the protection berm (m); $\boldsymbol{g}$ is the acceleration due to gravity $\left(\mathrm{m} / \mathrm{s}^{2}\right) ; H$ is the wave height $(\mathrm{m}) ; R_{\mathrm{u}}$ is the run-up of the liquid vein (m); $T$ is the wave period (s); $y$ is the distance between the berm's crown and the end of the run-up (m); $s$ is the stretch of wave wall protected by the armour layer (m); $\alpha$ is the angle of the armour layer's slope to the horizontal (sexagesimal degrees); $\beta$ is the angle the liquid vein forms (Günbak gives it a value of 15 sexagesimal degrees); and $\gamma$ is the specific weight of the water $\left(\mathrm{kN} / \mathrm{m}^{3}\right)$.

\subsubsection{Martín et al. (1995)}

The method described by Martín et al. (1995) gives two diagrams for pressures on the wave wall: the dynamic pressure corresponds to the deceleration of the wave's front and the pseudohydrostatic pressure occurs during the descent of the mass of water accumulated on the structure. The pressures are as shown in Figure 6.

\section{8. $\quad P_{\mathrm{d}}=\alpha \rho g s \quad A_{\mathrm{c}}<z<A_{\mathrm{c}}+s$}



Figure 5. Pressure distribution according to Günbak and Göcke. Source: Negro et al. (2008) 


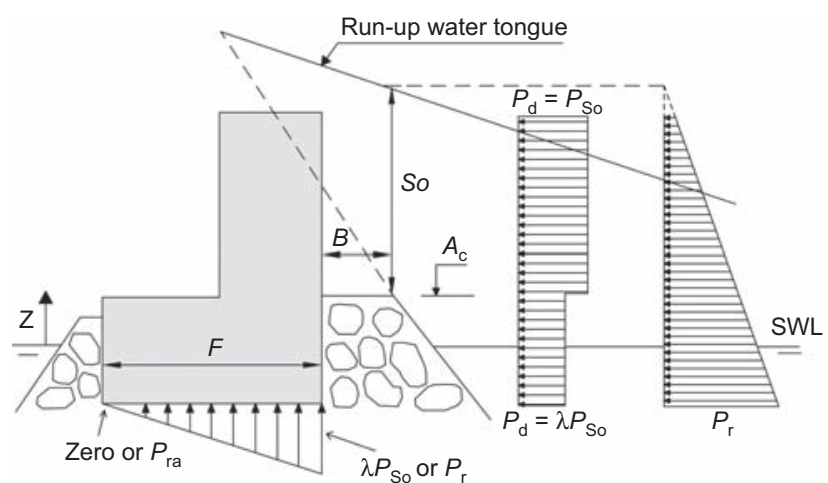

Figure 6. Pressure distribution according to Martín et al.; SWL, low sea level. Source: adapted from Martín et al. (1995)

9. $\quad P_{\mathrm{d}}=\lambda \alpha \rho g S$ foundation level $<z<A_{\mathrm{c}}$

10. $\alpha=2 \frac{R_{\mathrm{u}}}{H} \cos ^{2} \beta \cos ^{2} \theta$

11. $s=H\left(1-\frac{A_{\mathrm{c}}}{R_{\mathrm{u}}}\right)$

12. $\frac{R_{\mathrm{u}}}{H}=A_{\mathrm{u}}\left[1-\exp \left(B_{\mathrm{u}} I_{\mathrm{r}}\right)\right]$

(run-up according to Losada (1990))

The $\lambda$ parameter reduces the pressure due to the presence of the armour layer. It is calculated with Figure 7, which was obtained by means of reduced model tests. The $A_{\mathrm{u}}$ and $B_{\mathrm{u}}$ coefficients are those referred to in Table 1.



Figure 7. Adjusted values of $\lambda$ (Martín et al.'s method.). Source: Negro et al. (2008)

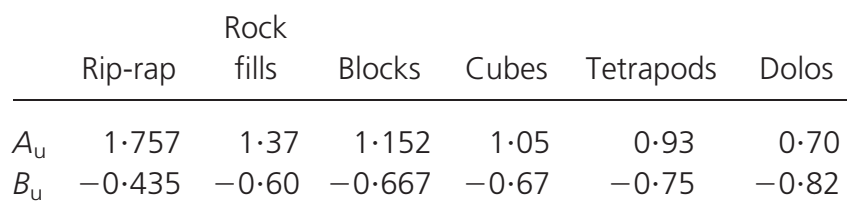

Table 1. Parameters $A_{\mathrm{u}}$ and $B_{\mathrm{u}}$ for calculating run-up (Martín et al.'s method). Source: Negro et al. (2008)

13.

$P_{\mathrm{h}}(z)=\mu \rho \boldsymbol{g}\left(s+A_{\mathrm{c}}-z\right)$ foundation level $<z<A_{\mathrm{c}}+s$

The value of $\mu$ is obtained from Figure 8 .

The uplift pressures are calculated by following the condition of continuity at the foot located on the attack side. It indicates the following for the sheltered point.

- There is nil uplift pressure for the dynamic pressures if the foundation level is above high tide. If not, it will be calculated taking into account the buoyancy of the submerged part and the wave transmitted through the porous medium $\left(\lambda P_{\mathrm{d}}\right)$.

- In the case of pseudohydrostatic pressure, the uplift pressure at the sheltered point is calculated according to a trapezoidal law on the side of safety as to a parabolic pressure distribution, $\left(P_{\text {ra }}\right)$, according to the method developed by Martín et al. (1995) (Figure 9).

The notation is defined as: $\alpha$ is the non-dimensional parameter containing information on the celerity of the mass of water $s$ wide at level $A_{\mathrm{c}} ; \beta$ is the angle formed by the main armour layer slope with the horizontal (sexagesimal degrees); $\lambda$ is the nondimensional parameter introducing the berm's effect into the pressures on the wave wall's protected area; $\mu$ is a non-

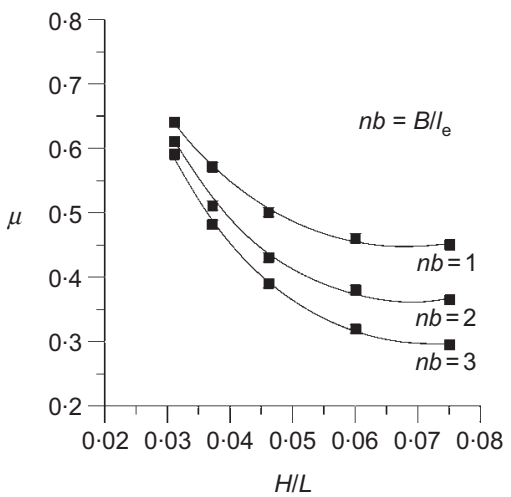

Figure 8. Adjusted values of $\mu$ (Martín et al.'s method). Source: Negro et al. (2008) 


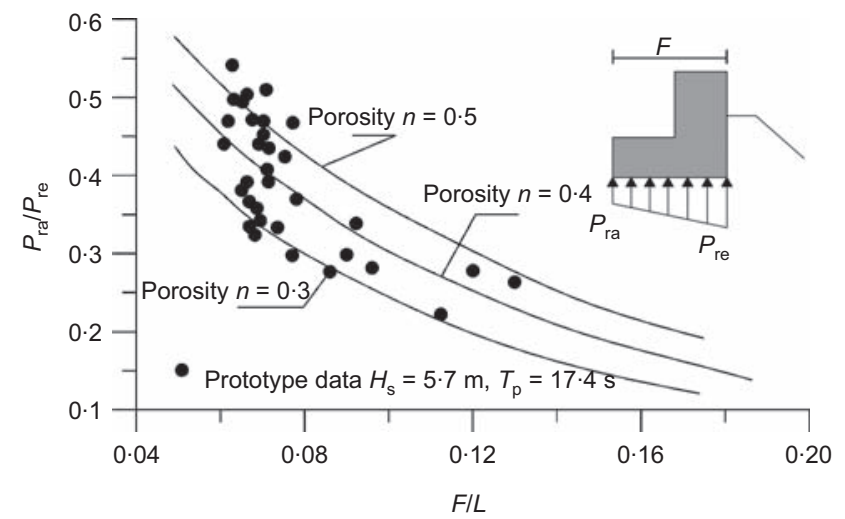

Figure 9. Uplift pressures (Martín et al.'s method). Source: adapted from Martín et al. (1995)

dimensional parameter less than $1 ; \rho$ is the sea water density $\left(\mathrm{kN} . \mathrm{s}^{2} / \mathrm{m}^{4}\right)$ such that $\rho g=\gamma_{\mathrm{w}}\left(\mathrm{kN} / \mathrm{m}^{3}\right) ; A_{\mathrm{c}}$ is the level of the rock fill or block berm's crown (m); $B$ is the width of the rock fill or block berm (m); $d$ is the depth (m); $\boldsymbol{g}$ is the acceleration due to gravity $\left(\mathrm{m} / \mathrm{s}^{2}\right)$ such that $\rho g=\gamma_{\mathrm{w}}\left(\mathrm{kN} / \mathrm{m}^{3}\right) ; H$ is the design wave height $(\mathrm{m}) ; H_{\mathrm{b}}$ is the height of breaking wave $(\mathrm{m}) ; H_{\mathrm{s}}$ is the height of significant wave $(\mathrm{m}) ; I_{\mathrm{r}}$ is the Iribarren number in deep water conditions; $L$ is the length of design wave (m); $I_{\mathrm{e}}$ is the equivalent side of the main armour layer's units $(\mathrm{m}) ; P_{\mathrm{b}}$ is the pseudohydrostatic pressure $\left(\mathrm{kN} / \mathrm{m}^{2}\right) ; P_{\mathrm{d}}$ is the dynamic pressure $\left(\mathrm{kN} / \mathrm{m}^{2}\right) ; R_{\mathrm{a}}$ is the run-up, namely the maximum ascent of the sheet of water on the slope, an undefined case (m); $s$ is the width of the sheet of water ascending on the slope at level $A_{\mathrm{c}}(\mathrm{m}) ; T$ is the design wave period (s); $T_{\mathrm{p}}$ is the peak period (s); and $z$ is the vertical coordinate with its origin at design sea level and positive in an ascending direction (m).

The dynamic and pseudohydrostatic pressures are not added up for calculating the wave wall's stability but each is separately dealt with and the sliding and overturning safety coefficients are obtained for each using the Goda criterion (Goda, 1985).

\subsection{Force diagram}

\subsubsection{Bradbury and Allsop (1988)}

This method starts from Jensen's work (Jensen, 1984) and determines the maximum horizontal force $F_{\mathrm{H}}$ on the wave wall.

Jensen does not give a specific equation but, based on test results, points out that there is a practically linear relationship between two factors

$$
\frac{F_{\mathrm{H}}}{\gamma_{\mathrm{w}} h b L_{\mathrm{P}}} \text { and } \frac{H_{\mathrm{S}}}{\Delta h}
$$

where $F_{\mathrm{H}}$ is the maximum horizontal force $(\mathrm{kN} / \mathrm{m}) ; \gamma_{\mathrm{w}}$ is the specific weight of sea water $\left(\mathrm{kN} / \mathrm{m}^{3}\right) ; h$ is the height of the wall (m); $b$ is the width of the wall (m); $L_{\mathrm{p}}$ is the peak period wave length $(\mathrm{m}) ; H_{\mathrm{S}}$ is the significant wave height $(\mathrm{m}) ; \Delta h$ is the vertical distance from still-water to the crest of the armour layer $(\mathrm{m})$.

Bradbury and Allsop (1988) propose the following equation from the foregoing

14. $\frac{F_{\mathrm{H}}}{\left(\rho g h_{\mathrm{f}} L_{p}\right)}=\frac{a H_{\mathrm{S}}}{A_{\mathrm{c}}}-b$

where $F_{\mathrm{H}}$ is the maximum horizontal force $(\mathrm{kN}) ; \rho$ is the sea water density $\left(\mathrm{kN} . \mathrm{s}^{2} / \mathrm{m}^{4}\right) ; \boldsymbol{g}$ is the acceleration due to gravity $\left(\mathrm{m} / \mathrm{s}^{2}\right)$, such that $\rho g=\gamma_{\mathrm{w}}\left(\mathrm{kN} / \mathrm{m}^{3}\right) ; h_{\mathrm{f}}$ is the height of wave wall (m); $L_{\mathrm{p}}$ is the peak period wave length (m); $H_{\mathrm{S}}$ is the significant wave height $(\mathrm{m}) ; A_{\mathrm{C}}$ is the protection layer crown height $(\mathrm{m})$; and $a, b$ are empirical coefficients as shown in Figure 10.

It assumes a rectangular horizontal pressure distribution to obtain an estimate on the side of safety

\section{5. $p_{\mathrm{H}}=F_{\mathrm{H}} / h_{\mathrm{f}}($ uniform horizontal pressure)}

The maximum vertical pressure coincides with the maximum horizontal. It takes up a triangular distribution having the maximum value at the front and reduces linearly to zero in the extrados with which the maximum vertical force is

16. $F_{\mathrm{V}}=\left(\rho g B_{\mathrm{c}} L_{\mathrm{p}} / S\right)\left(a H_{\mathrm{S}} / A_{\mathrm{c}}-b\right)$

where $S$ is a safety factor and $B_{\mathrm{c}}$ is the width of the crown wall. The method proposes a coefficient of friction $\mu$ with a value of 0.50 for calculating the wave wall's stability. This is the method proposed by CIRIA-CUR (1991).

\subsubsection{Pedersen and Burcharth (1992)}

The horizontal force is obtained from the pressure records by spatial integration. The study confirms the investigations provided by Jensen, explained in the foregoing section. The equation proposed by Pedersen and Burcharth is as follows

17. $\frac{F_{\mathrm{h}, 0 \cdot 1 \%}}{\rho \boldsymbol{g} h_{\mathrm{f}} L_{\mathrm{p}}}=a\left(\frac{H_{\mathrm{S}}}{A_{\mathrm{c}}}+b\right)$

where: $F_{\mathrm{h}, 0 \cdot 1 \%}$ is the horizontal force associated with a surplus of $0 \cdot 1 \%(\mathrm{kN}) ; \rho$ is the water density $\left(\mathrm{kN} . \mathrm{s}^{2} / \mathrm{m}^{4}\right) ; \boldsymbol{g}$ is the acceleration due to gravity $\left(\mathrm{m} / \mathrm{s}^{2}\right)$, such that $\rho g=\gamma_{\mathrm{w}}\left(\mathrm{kN} / \mathrm{m}^{3}\right) ; h_{\mathrm{f}}$ is the height of wave wall (m); $L_{\mathrm{p}}$ is the peak period wave length (m); $H_{\mathrm{S}}$ is the significant wave height $(\mathrm{m}) ; A_{\mathrm{c}}$ is the protection layer's crown height $(\mathrm{m})$; and $a, b$ are non-dimensional coefficients to be determined with specific tests. 


\begin{tabular}{|c|c|c|c|c|c|c|c|c|}
\hline \multirow[b]{3}{*}{ Coefficient } & \multicolumn{4}{|c|}{ Massive concrete blocks } & \multicolumn{4}{|c|}{ Natural rock } \\
\hline & \multicolumn{2}{|c|}{ No break } & \multicolumn{2}{|c|}{ Break } & \multicolumn{2}{|c|}{ No break } & \multicolumn{2}{|c|}{ Break } \\
\hline & $\varepsilon_{\mathrm{dp}} \leq 3 \cdot 25$ & $\varepsilon_{\mathrm{dp}}>3 \cdot 25$ & $\varepsilon_{\mathrm{dp}} \leq 3 \cdot 25$ & $\varepsilon_{\mathrm{dp}}>3 \cdot 25$ & $\varepsilon_{\mathrm{dp}} \leq 3 \cdot 25$ & $\varepsilon_{\mathrm{dp}}>3 \cdot 25$ & $\varepsilon_{\mathrm{dp}} \leq 3 \cdot 25$ & $\varepsilon_{\mathrm{dp}}>3 \cdot 25$ \\
\hline a & 0.0121 & 0.0118 & $0 \cdot 0100$ & 0.0093 & 0.0118 & 0.0103 & 0.0114 & 0.0044 \\
\hline$b$ & -0.0094 & -0.0119 & -0.0067 & -0.0084 & -0.0115 & -0.0129 & -0.0103 & -0.0024 \\
\hline
\end{tabular}

Table 2. Coefficients for calculating horizontal force (Berenguer and Baonza's method). Source: Negro et al. (2008)

\subsubsection{Berenguer and Baonza (2006)}

Determining forces on a wave wall calls for calculating the runup according to the formulation indicated in the method proposed by Berenguer and Baonza (2006)

18. $R_{\mathrm{u} 2 \%}=0 \cdot 86 \xi_{\mathrm{p}}^{0.54} H_{\mathrm{S}} \gamma_{\theta}$

where $R_{\mathrm{u} 2} \%$ is the ascent of the sheet of water exceeded by $2 \%$ of the waves (m); $H_{\mathrm{s}}$ is the significant wave height (m); $\xi_{\mathrm{p}}$ is the Iribarren number referring to the length of wave associated with the peak period; and $\gamma_{\theta}$ is the obliqueness factor according to De Waal's criterion (De Waal et al., 1996).

\subsubsection{HORIZONTAL FORCE}

19. $F_{\mathrm{X}}=\gamma_{\mathrm{w}} h_{\mathrm{h}}^{0 \cdot 5} L_{\mathrm{p}}^{1 \cdot 5}\left(a \frac{R_{\mathrm{u} 2 \%}}{A_{\mathrm{c}}^{2 / 3} B^{1 / 3}}+b\right)$ if $\left(R_{\mathrm{u} 2 \%}>R_{\mathrm{c}}\right)$

$$
F_{\mathrm{X}}=\gamma_{\mathrm{w}}\left(R_{\mathrm{u} 2 \%}-W_{\mathrm{c}}\right)^{0.5}
$$

20.

$$
\times L_{\mathrm{p}}^{1 \cdot 5}\left(a \frac{R_{\mathrm{u} 2 \%}}{A_{\mathrm{c}}^{2 / 3} B^{1 / 3}}+b\right) \text { if }\left(R_{\mathrm{u} 2 \%} \leq R_{\mathrm{c}}\right)
$$

The $a$ and $b$ coefficients of the foregoing equations are obtained from Table 2.

\subsubsection{VERTICAL FORCE (UPLIFT PRESSURE)}

21. $F_{\mathrm{Y}}=\gamma_{\mathrm{w}} h_{\mathrm{h}}^{0.5} L_{\mathrm{p}}^{1 \cdot 5}\left(a \frac{R_{\mathrm{u} 2 \%}-W_{\mathrm{c}}}{A_{\mathrm{c}}^{2 / 3} B^{1 / 3}}+b\right)$ if $\left(R_{\mathrm{u} 2 \%}>R_{\mathrm{c}}\right)$

$$
\begin{aligned}
F_{\mathrm{Y}}= & \gamma_{\mathrm{w}}\left(R_{\mathrm{u} 2 \%}-W_{\mathrm{c}}\right)^{0 \cdot 5} \\
& \times L_{\mathrm{p}}^{1.5}\left(a \frac{R_{\mathrm{u} 2 \%}-W_{\mathrm{c}}}{A_{\mathrm{c}}^{2 / 3} B^{1 / 3}}+b\right) \text { if }\left(R_{\mathrm{u} 2 \%} \leq R_{\mathrm{c}}\right)
\end{aligned}
$$

22.

The $a$ and $b$ coefficients of the foregoing equations are obtained from Table 3.

If a wave wall with a base $F$ is considered, the total uplift pressure will be

\begin{tabular}{|c|c|c|c|c|c|c|c|c|}
\hline \multirow[b]{3}{*}{ Coefficient } & \multicolumn{4}{|c|}{ Massive concrete blocks } & \multicolumn{4}{|c|}{ Natural rock } \\
\hline & \multicolumn{2}{|c|}{ No break } & \multicolumn{2}{|c|}{ Break } & \multicolumn{2}{|c|}{ No break } & \multicolumn{2}{|c|}{ Break } \\
\hline & $\varepsilon_{\mathrm{dp}} \leq 3 \cdot 25$ & $\varepsilon_{\mathrm{dp}}>3 \cdot 25$ & $\varepsilon_{\mathrm{dp}} \leq 3 \cdot 25$ & $\varepsilon_{\mathrm{dp}}>3 \cdot 25$ & $\varepsilon_{\mathrm{dp}} \leq 3 \cdot 25$ & $\varepsilon_{\mathrm{dp}}>3 \cdot 25$ & $\varepsilon_{\mathrm{dp}} \leq 3 \cdot 25$ & $\varepsilon_{\mathrm{dp}}>3 \cdot 25$ \\
\hline a & 0.0015 & 0.0004 & 0.0001 & 0.0014 & 0.0024 & $0 \cdot 0014$ & 0.0016 & 0.0001 \\
\hline$b$ & 0.0020 & 0.0028 & 0.0037 & 0.0017 & 0.0013 & 0.0012 & $0 \cdot 0025$ & 0.0034 \\
\hline
\end{tabular}

$$
\begin{aligned}
F_{\mathrm{YT}} & =F_{\mathrm{Y}}+F_{\mathrm{Y}} \\
& =F_{\mathrm{Y}}+\left(0 \cdot 017 L_{\mathrm{p}}-0 \cdot 109 F\right)\left(F-0.043 L_{\mathrm{p}}\right)
\end{aligned}
$$

\subsubsection{MOMENT DUE TO THE HORIZONTAL FORCE}

24. $M_{\mathrm{X}}=\gamma_{\mathrm{w}} h_{\mathrm{f}} L_{\mathrm{p}}^{2}\left(a \frac{F_{\mathrm{X}}}{\gamma_{\mathrm{w}} h_{\mathrm{f}}^{0 \cdot 5} L_{\mathrm{p}}^{1 \cdot 5}}+b\right)$ if $\left(R_{\mathrm{u} 2 \%}>R_{\mathrm{c}}\right)$

Table 3. Coefficients for calculating vertical force (Berenguer and Baonza's method). Source: Negro et al. (2008) 


\begin{tabular}{|c|c|c|c|c|c|c|c|c|}
\hline \multirow[b]{3}{*}{ Coefficient } & \multicolumn{4}{|c|}{ Massive concrete blocks } & \multicolumn{4}{|c|}{ Natural rock } \\
\hline & \multicolumn{2}{|c|}{ No break } & \multicolumn{2}{|c|}{ Break } & \multicolumn{2}{|c|}{ No break } & \multicolumn{2}{|c|}{ Break } \\
\hline & $\varepsilon_{\mathrm{dp}} \leq 3 \cdot 25$ & $\varepsilon_{\mathrm{dp}}>3 \cdot 25$ & $\varepsilon_{\mathrm{dp}}>3 \cdot 25$ & $\varepsilon_{\mathrm{dp}}>3 \cdot 25$ & $\varepsilon_{\mathrm{dp}} \leq 3 \cdot 25$ & $\varepsilon_{\mathrm{dp}}>3 \cdot 25$ & $\varepsilon_{\mathrm{dp}} \leq 3 \cdot 25$ & $\varepsilon_{\mathrm{dp}}>3 \cdot 25$ \\
\hline a & $0 \cdot 113370$ & $0 \cdot 109490$ & $0 \cdot 119270$ & 0.062150 & $0 \cdot 123997$ & 0.096651 & $0 \cdot 121971$ & 0.071884 \\
\hline$b$ & 0.000190 & $-0 \cdot 000080$ & $0 \cdot 000040$ & 0.000060 & -0.000002 & -0.000067 & -0.000072 & 0.000008 \\
\hline
\end{tabular}

Table 4. Coefficients for calculating the moment of the horizontal force (Berenguer and Baonza's method). Source: Negro et al. (2008)

25.

$$
\begin{aligned}
M_{\mathrm{X}}= & \gamma_{\mathrm{w}}\left(R_{\mathrm{u} 2 \%}-W_{\mathrm{c}}\right) \\
& \times L_{\mathrm{p}}^{2}\left[a \frac{F_{\mathrm{X}}}{\gamma_{\mathrm{w}}\left(R_{\mathrm{u} 2 \%}-W_{\mathrm{c}}\right)^{0 \cdot 5} L_{\mathrm{p}}^{1 \cdot 5}}+b\right] \text { if }\left(R_{\mathrm{u} 2 \%} \leq R_{\mathrm{c}}\right)
\end{aligned}
$$

The $a$ and $b$ coefficients of the foregoing equations are obtained from Table 4.

\subsubsection{MOMENT DUE TO THE VERTICAL FORCE (UPLIFT PRESSURE)}

26.

$$
\begin{aligned}
M_{Y T}= & F_{Y}\left(F-0.018 L_{p}\right)+\left(F_{Y T}-F_{Y}\right) \\
& \times\left(\frac{0.046 L_{p}-0.217 F}{0.102 L_{p}-0.651 F}\right)\left(F-0.043 L_{p}\right)
\end{aligned}
$$

where $F_{\mathrm{X}}$ is the horizontal force exerted by waves on the wave wall $(\mathrm{kN}) ; F_{\mathrm{YT}}$ is the vertical force (uplift pressure) exerted by waves on the wave wall $(\mathrm{kN}) ; M_{\mathrm{X}}$ is the moment due to horizontal force $(\mathrm{kN} . \mathrm{m}) ; M_{\mathrm{Y}}$ is the moment due to vertical force (uplift pressure) (kN.m); $\gamma_{\mathrm{w}}$ is the specific weight of water $\left(\mathrm{kN} / \mathrm{m}^{3}\right) ; W_{\mathrm{c}}$ is the wave wall's foundation level as to sea level (m); $R_{\mathrm{c}}$ is the wave wall's crown level as to sea level (m); $L_{\mathrm{p}}$ is the wave length at foot of breakwater as to peak period (m); $A_{\mathrm{c}}$ is the berm crown level as to sea level (m); $B$ is the width of crown berm (m); $h_{\mathrm{f}}$ is the height of the wave wall (m); $\operatorname{tg} \alpha$ is the tangent of the armour layer slope angle with the horizontal; and $\theta$ is the waves' angle of incidence (sexagesimal degrees).

\section{Critical analysis of the methods}

The foregoing methods have their ranges of use and application. They have been generally obtained under laboratory conditions, which should be borne in mind to be able to properly interpret the results. The peculiarities of each method as taken from the pertinent investigations are discussed hereafter. The analysis is carried out in a chronological order to observe the variation of the parameters used in the calculations in time.

\subsection{Iribarren and Nogales (1954)}

- The method proposed by Iribarren and Nogales (1954) stands out for being the first wave wall calculation method.
It dates from 1954 and no other alternative calculation method appeared until 1984 (Günbak and Göcke, 1984).

- The breakwater on which the pressures indicated are applied corresponds to a specific geometry recommended by

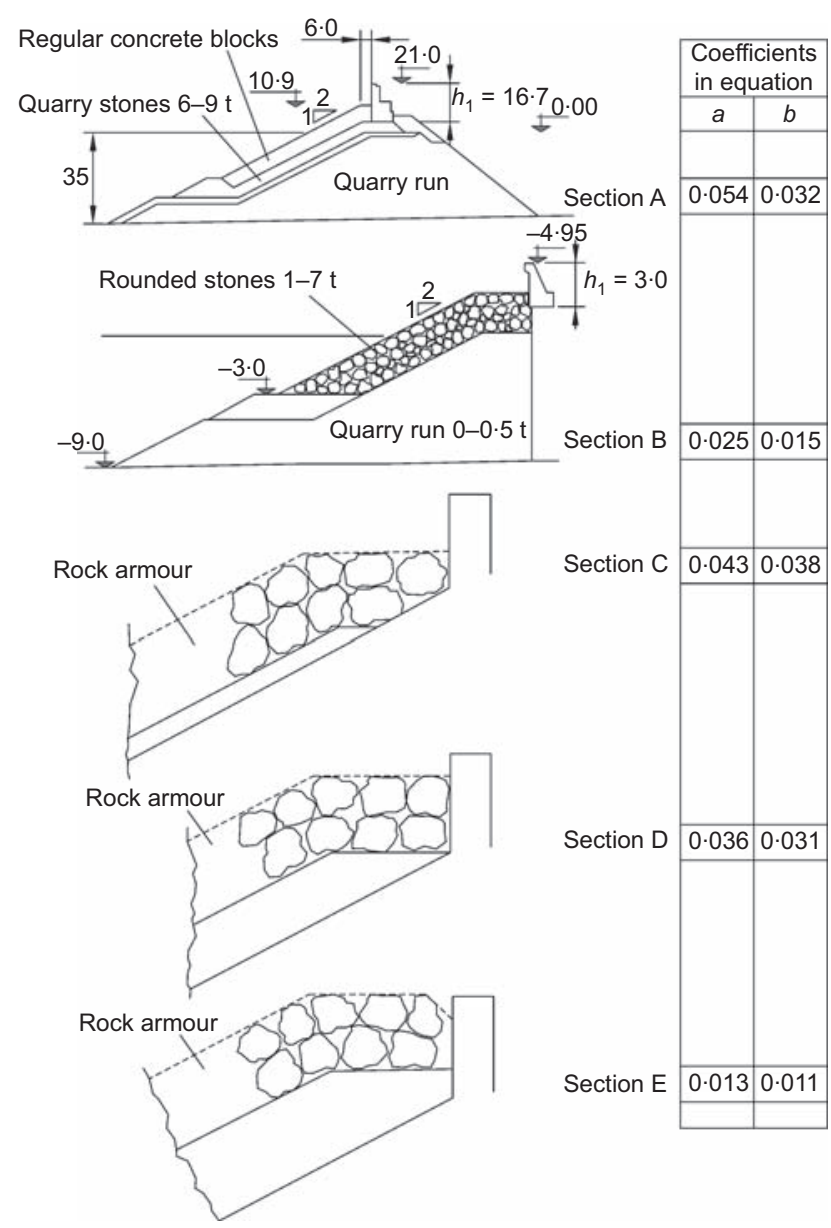

Figure 10. Values of empirical parameters according to geometries tested for the Bradbury and Allsop method. Source: Negro et al. (2008) 




Figure 11. Typical breakwater cross-section according to Iribarren and Nogales. Source: Negro et al. (2008)

Iribarren and Nogales. Applying the method for another type of geometry would not be recommendable. The geometry Iribarren and Nogales indicate is that as represented by Figure 11. The method requires the waves to arrive at the wave wall broken, whether because they are broken when incident on the breakwater or because they break on the armour layer's slope.

- It only indicates horizontal pressures and does not specify the uplift pressures appearing on the wave wall with a wave height of $A=1 \cdot 25 H$, where $H=2 h$.

- It poses passing pressures that represent the horizontal speed of the wave crest and dynamic pressures corresponding to the fall of molecules into the trough. The resulting horizontal pressure is the sum of them both.

- The block layer located in front of the wave wall reduces the total pressures $50 \%$.

- The parameters intervening do not include the length of the

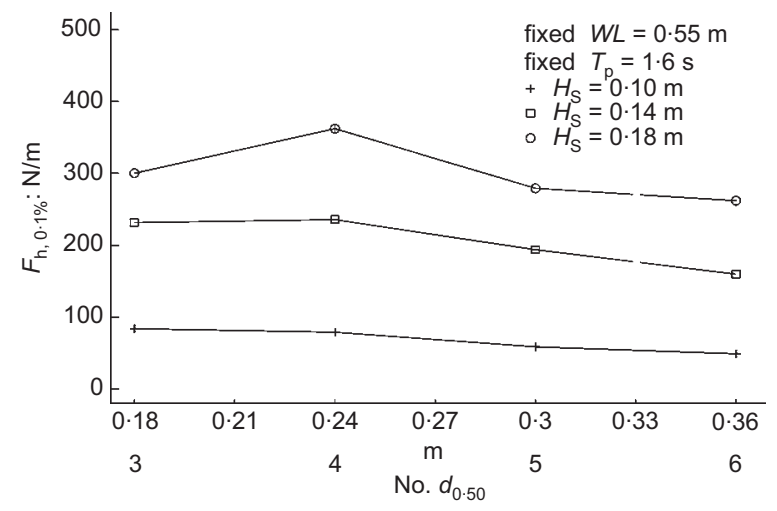

Figure 12. Influence of the berm's width on the total horizontal force on the wave wall according to Pedersen and Burcharth. Source: adapted from Pedersen and Burcharth (1992) protection berm located facing the wave wall. It does not assess the influence of the number of units in the armour layer facing the wall on reducing pressure.

- It does not indicate the wave height to be considered in the calculation $\left(H_{1 / 250}, H_{2 \%}, H_{\mathrm{S}}, H_{1 / 10}\right)$.

\subsection{Günbak and Göcke (1984)}

- Günbak and Göcke (1984) devised this procedure in order to calculate 'wave screen' type structures. Nevertheless, it does not specify the range of validity or application.

- In the tests on which it is based, waves break before becoming incident on the wave wall.

- The authors point out that the method has been thought up to be applied in Mediterranean ports. This aspect is relevant since each sea behaves differently and is not entirely picked up by the Günbak and Göcke method parameters, such as

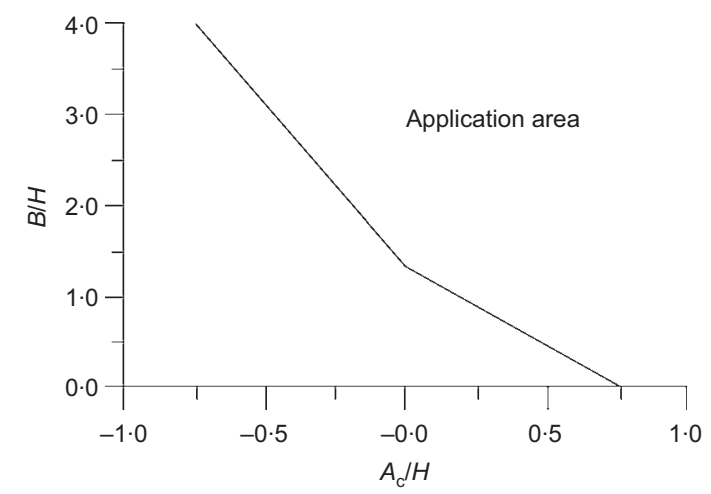

Figure 13. Range of validity of Martín et al.'s method. Source: Negro et al. (2008) 


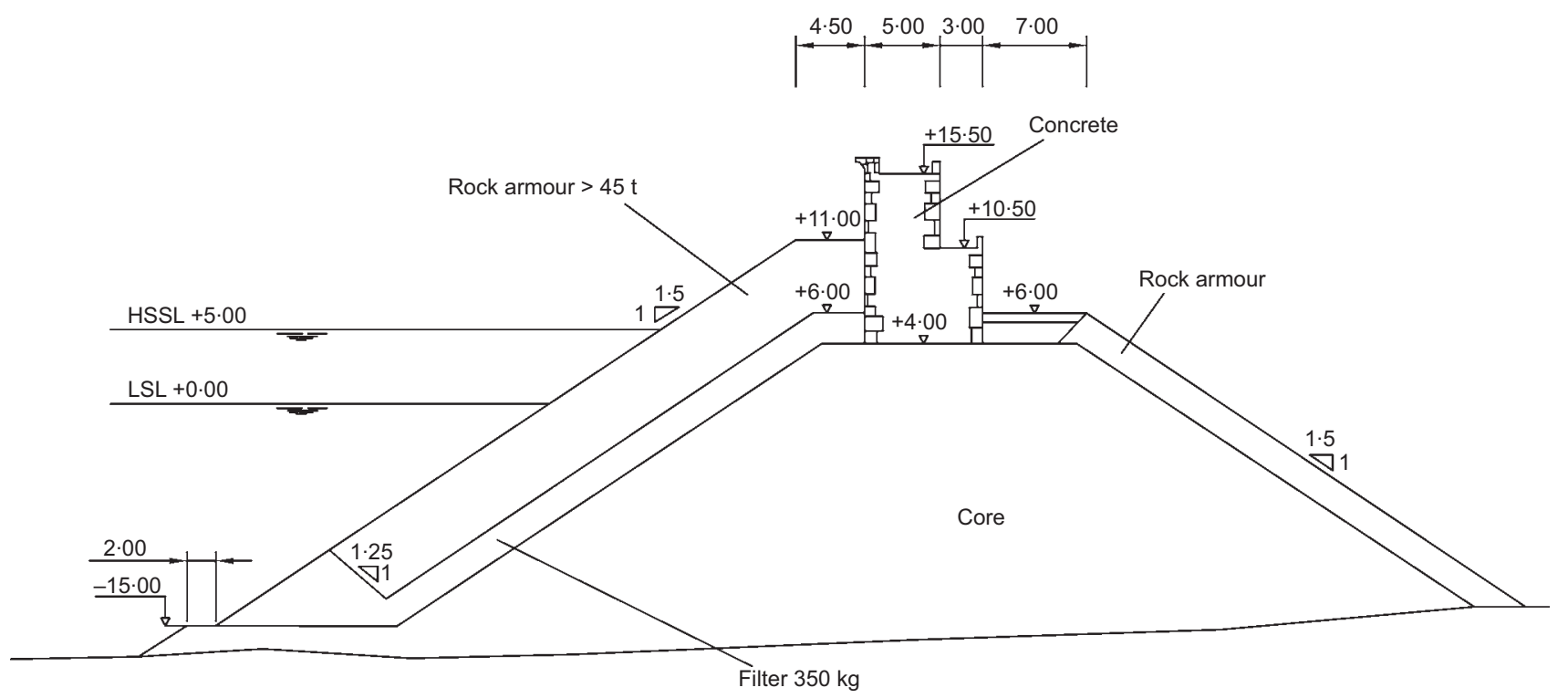

Figure 14. Mutriku new breakwater section S-3 (dimensions and elevations in $\mathrm{m}$ ); HSSL, high still sea level; LSL, low sea level

the wave length and number of waves (a particularly relevant factor in breakwaters as made patent in Van der Meer's equation (Van der Meer, 1993). Applying it to ports located in other masses of water, the North Atlantic for example, should be previously studied.

- There are two pressures: shock and hydrostatic. The resulting pressure is the sum of them both.

a It considers that the existence of a berm facing the wave wall reduces the shock pressure at the foot of the wall $50 \%$. This reduction is gradual, with no leap.

- It does not define the wave height which has to be used nor to what location the Iribarren number refers, which is that used to calculate run-up and pressures.

- It carries out a number of tests on eight different crosssections, though with the same slope $(1 \mathrm{~V} / 2 \mathrm{H})$. Nevertheless, the actual ports where it contrasts the results (Tripoli and Antalya) have slopes of $1 \mathrm{~V} / 1 \cdot 5 \mathrm{H}$ and $1 \mathrm{~V} / 2 \cdot 5 \mathrm{H}$.

- Based on the tests, it concludes that there should be at least three units of the armour layer facing the wave wall in order to be able to consider the $50 \%$ reduction in the impact pressures. The length of the armour layer located facing the wave wall does not intervene in the formulation and it is

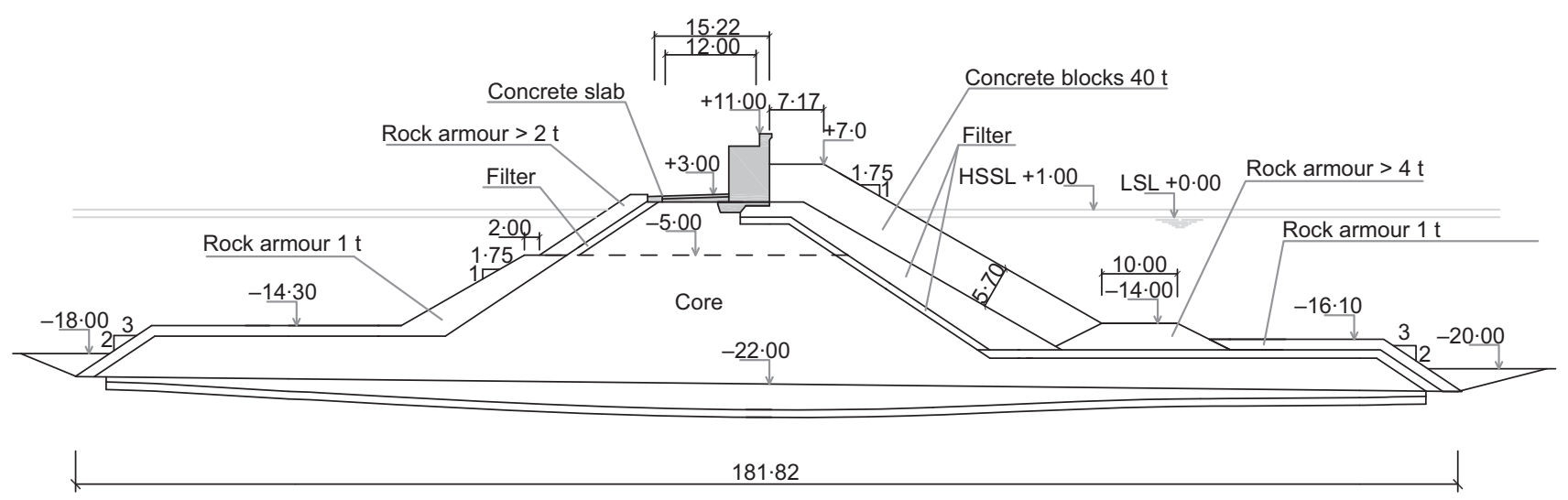

Figure 15. Barcelona South breakwater section (dimensions and elevations in m); HSSL, high still sea level; LSL, low sea level 
Mutriku new breakwater

Crown wall weight $\left(\gamma_{\mathrm{HM}}=2 \cdot 3 \mathrm{t} / \mathrm{m}^{3}\right)$

Crown wall weight arm

Stability moment due to crown wall weight

Width of the foundation

Specific weight of water

Acceleration due to gravity, such that $\rho g=\gamma_{w}\left(k N / m^{3}\right)$

Specific weight of armour elements

Maximum variability of sea water level

Return period of the structure

Calculation wave height (Iribarren and Nogales, Günbak-Göcke and Martín et al.). $H_{2 \%} \approx 1 \cdot 416 H_{s}$

Significant wave height

Peak period wave length in toe berm

Calculation wave period

Peak period

Wave incidence angle

Main armour elements equivalent length

Friction coefficient
$169 \mathrm{t} / \mathrm{m}$

$4.51 \mathrm{~m}$

762 t.m

$8.00 \mathrm{~m}$

$1.02 \mathrm{t} / \mathrm{m}^{3}$

$9 \cdot 81 \mathrm{~m} / \mathrm{s}^{2}$

$2 \cdot 3 \mathrm{t} / \mathrm{m}^{3}$

$5.00 \mathrm{~m}$

112 years

$10.62 \mathrm{~m}$

$7.50 \mathrm{~m}$

$18265 \mathrm{~m}$

$15 \cdot 7 \mathrm{~s}$

$15 \cdot 7 \mathrm{~s}$

0.0 degrees

$>45 \mathrm{t} \rightarrow 2.6 \mathrm{~m}$

$0 \cdot 5$

Barcelona South breakwater

Crown wall weight $\left(\gamma_{\mathrm{HM}}=23 \mathrm{kN} / \mathrm{m}^{3}\right)$

Crown wall weight arm

Stability moment due to crown wall weight

Width of the foundation

Specific weight of water

Acceleration due to gravity, such that $\rho \boldsymbol{g}=\gamma_{\mathrm{w}}\left(\mathrm{kN} / \mathrm{m}^{3}\right)$

Specific weight of armour elements

Maximum variability of sea water level

Return period of the structure

Calculation wave height (Iribarren and Nogales, Günbak-Göcke and Martín et al.). $H_{2 \%} \approx 1 \cdot 416 H_{s}$

Significant wave height

Peak period wave length in toe berm

Calculation wave period

Peak period

Wave incidence angle

Main armour elements equivalent length

Depth

Friction coefficient without key

Friction coefficient with key
$133 \mathrm{t} / \mathrm{m}$

$2 \cdot 88 \mathrm{~m}$ (without slab)

383 t.m

$6 \cdot 85 \mathrm{~m}$ (without slab)

$1.02 \mathrm{t} / \mathrm{m}^{3}$

$9 \cdot 81 \mathrm{~m} / \mathrm{s}^{2}$

$2 \cdot 3 \mathrm{t} / \mathrm{m}^{3}$

$1.00 \mathrm{~m}$

500 years

$10 \cdot 62 \mathrm{~m}$

$7 \cdot 5 \mathrm{~m}$

$182 \cdot 62 \mathrm{~m}$

$14 \mathrm{~s}$

$14 \mathrm{~s}$

$0 \cdot 0$ degrees

$50 \mathrm{t} \rightarrow 2.79 \mathrm{~m}$

$20 \mathrm{~m}$

0.5

$0 \cdot 6$

Table 5. Case data

therefore assumed that it must always be equal to the length equivalent to three units of the armour layer.

\subsection{Bradbury and Allsop (1988)}

- The method proposed by Bradbury and Allsop (1988) is based on Jensen's investigations.

- The formulation offers the horizontal force as the result.
From there it passes to horizontal pressure, adopting a uniform pressure distribution over the whole height of the wave wall, and to uplift pressures, assuming a triangular distribution although it indicates that rectangular should be taken to be on the side of safety. It is supposed, with these pressures, that the arms of the forces would be obtained in order to calculate the moment, but no specification is given. 


\begin{tabular}{|c|c|c|c|c|c|c|}
\hline \multirow[b]{2}{*}{ Example } & \multirow{2}{*}{\multicolumn{2}{|c|}{ Method }} & \multicolumn{4}{|c|}{ Loads } \\
\hline & & & $F_{H}$ & $F_{\mathrm{V}}$ & $M_{F H}$ & $M_{\mathrm{FV}}$ \\
\hline \multirow{7}{*}{ Mutriku new breakwater } & Iribarren and Nogales & & 962 & 531 & 3414 & 2832 \\
\hline & Günbak and Göcke & & 943 & 530 & 4267 & 2826 \\
\hline & Bradbury and Allsop & & 913 & 318 & 5252 & 847 \\
\hline & Pedersen and Burcharth & & - & - & - & - \\
\hline & & Dynamic & 550 & 153 & 3547 & 817 \\
\hline & Martin et al. & Pseudohydrostatic & 265 & 277 & 1015 & 1231 \\
\hline & Berenguer and Baonza & & 1067 & 251 & 4313 & 1184 \\
\hline \multirow{7}{*}{$\begin{array}{l}\text { Barcelona } \\
\text { South } \\
\text { breakwater }\end{array}$} & Iribarren and Nogales & & 694 & 455 & 1874 & 2076 \\
\hline & Günbak and Göcke & & 397 & 295 & 1179 & 1349 \\
\hline & Bradbury and Allsop & & 1409 & 536 & 6342 & 1225 \\
\hline & Pedersen and Burcharth & & - & - & - & - \\
\hline & & Dynamic & 382 & 103 & 1996 & 472 \\
\hline & Martín et al. & Pseudohydrostatic & 165 & 187 & 499 & 712 \\
\hline & Berenguer and Baonza & & 916 & 294 & 4795 & 1068 \\
\hline \multirow{7}{*}{$\begin{array}{l}\text { Barcelona } \\
\text { South } \\
\text { breakwater }\end{array}$} & Iribarren and Nogales & & 694 & 455 & 1874 & 2076 \\
\hline & Günbak and Göcke & & $397 \cdot 2$ & $295 \cdot 4$ & $1179 \cdot 1$ & 1349 \\
\hline & Bradbury and Allsop & & 1409 & 536 & 6342 & 1225 \\
\hline & Pedersen and Burcharth & & - & - & - & - \\
\hline & \multirow{2}{*}{ Martín et al. } & Dynamic & 382 & 103 & 1996 & 472 \\
\hline & & Pseudohydrostatic & 165 & 187 & 499 & 712 \\
\hline & Berenguer and Baonza & & 916 & 294 & 4795 & 1068 \\
\hline
\end{tabular}

$F_{\mathrm{H}}$, horizontal force $(\mathrm{kN} / \mathrm{m}) ; F_{\mathrm{V}}$, vertical force $(\mathrm{kN} / \mathrm{m}) ; M_{\mathrm{FH}}$, instability moment associated with $F_{\mathrm{H}}(\mathrm{mkN} / \mathrm{m})$; $M_{\mathrm{FV}}$, instability moment associated with $F_{\vee}(\mathrm{mKN} / \mathrm{m})$.

Table 6. Example structures. Results obtained: forces

- It defines the wave height and wave length to be used in the calculations.

- The formulation has empirically obtained parameters that depend on the geometry of the berm and the filter and it is therefore assumed that all the peculiarities of those elements are taken into account. The reference coefficients for cases which do not match the cross-sections indicated would have to be obtained.

- The breakwater cross-sections have a $1 V / 2 H$ slope. It points out that this slope usually takes a more unfavourable run-up.

- The formula does not show the armour layer's width. Nevertheless, the cross-sections in Figure 10 show the following: section A shows a filter of 6 to $9 \mathrm{t}$, which indicates that the armour layer must be formed by blocks between 60 and $140 \mathrm{t}$. This section encloses a berm distance of $6 \mathrm{~m}$, which allows two blocks, not three, to be placed. Sections C, D and E show a berm with a width corresponding to three units.

- It does not include any reduction in horizontal pressures because of the existence of an armour layer facing the wave wall.

\subsection{Pedersen and Burcharth (1992)}

- The Pedersen and Burcharth (1992) method calculates the horizontal force with a surplus of $0 \cdot 1 \%$ obtained by integrating the pressures recorded in laboratory tests. This formula has to be adjusted with the $a$ and $b$ parameters.

- The tests carried out hardly have any overtopping and the calculation method is therefore more reliable in breakwaters displaying a low overtopping rate.

- It is a formulation that is very similar to Bradbury and Allsop's. It does not pretend to be a new equation but confirms that given by Jensen (1984).

- It observes that the influence of the berm's width on the intensity of the pressures is low, as shown in Figure 12.

- It assumes that most of the load is due to hydrostatic pressure.

- It does not say how to calculate the vertical force to be considered.

- The empirical $a$ and $b$ parameters it introduces into the equation show the characteristics of the berm and the filter, the same as the Bradbury and Allsop (1988) method. However, these parameters have to be determined in laboratory tests. It does not provide predetermined values as in Bradbury and Allsop's method. 


\begin{tabular}{|c|c|c|c|c|}
\hline \multirow[b]{2}{*}{ Example } & \multirow{2}{*}{\multicolumn{2}{|c|}{ Method }} & \multicolumn{2}{|c|}{ Stability analysis } \\
\hline & & & CSD & CSV \\
\hline \multirow{8}{*}{ Mutriku new breakwater } & Iribarren and Nogales & & $0 \cdot 60$ & $1 \cdot 40$ \\
\hline & Günbak and Göcke & & 0.61 & $1 \cdot 12$ \\
\hline & Bradbury and Allsop & & 0.75 & $1 \cdot 29$ \\
\hline & Pedersen and Burcharth & & - & - \\
\hline & Martín et al & Dynamic & $1 \cdot 40$ & $1 \cdot 92$ \\
\hline & Midal tin el al. & Pseudohydrostatic & $2 \cdot 66$ & $6 \cdot 30$ \\
\hline & Berenguer and Baonza & & 0.67 & $1 \cdot 49$ \\
\hline & Iribarren and Nogales & & 0.63 & 0.94 \\
\hline \multirow{6}{*}{$\begin{array}{l}\text { Barcelona } \\
\text { South } \\
\text { breakwater }\end{array}$} & Günbak and Göcke & & $1 \cdot 30$ & $2 \cdot 11$ \\
\hline & Bradbury and Allsop & & $0 \cdot 28$ & 0.41 \\
\hline & Pedersen and Burcharth & & - & - \\
\hline & Martín et al & Dynamic & $1 \cdot 60$ & $1 \cdot 68$ \\
\hline & & Pseudohydrostatic & $3 \cdot 46$ & $6 \cdot 26$ \\
\hline & $\begin{array}{l}\text { Berenguer and } \\
\text { Baonza }\end{array}$ & & $0 \cdot 56$ & $0 \cdot 58$ \\
\hline \multirow{7}{*}{$\begin{array}{l}\text { Barcelona } \\
\text { South } \\
\text { breakwater }\end{array}$} & Iribarren and Nogales & & $0 \cdot 76$ & 0.94 \\
\hline & Günbak and Göcke & & $1 \cdot 56$ & $2 \cdot 11$ \\
\hline & Bradbury and Allsop & & $0 \cdot 34$ & 0.41 \\
\hline & Pedersen and Burcharth & & - & - \\
\hline & & Dynamic & $1 \cdot 93$ & $1 \cdot 68$ \\
\hline & Mrartin et al. & Pseudohydrostatic & $4 \cdot 15$ & $6 \cdot 26$ \\
\hline & Berenguer and Baonza & & $0 \cdot 68$ & 0.58 \\
\hline
\end{tabular}

CSD, sliding safety coefficient; CSV, overturning safety coefficient.

Table 7. Example structures. Results obtained: stability analyses

\subsection{Martín et al. (1995)}

- The Martín et al. (1995) method gives two pressures: a dynamic one (due to the deceleration of the wave's front) and a pseudohydrostatic one (due to the descent of the mass of water accumulated on the structure). It does not consider them to be concomitant, and, therefore, they are not added together and it studies the wave wall's stability in each case separately. It is the only calculation method operating in this way. The vertical pressure is parallelepiped or triangular depending on whether it is due to dynamic or pseudohydrostatic pressures.

- The methodology is applicable while the following conditions are fulfilled

(a) waves reach the wave wall either broken or in run-up

(b) the angle of incidence may be up to \pm 20 sexagesimal degrees

(c) must be inside the application region marked in Figure 13.

- It is an exhaustive method that considers a large number of factors not taken into account in the other procedures or included together with others in empirical parameters.
- It does not clearly define the wave height, wave length or period to be used in the calculation, and it is not known whether $H_{2 \%}, H_{\mathrm{S}}, H_{1 / 10}, H_{\max }$ are involved.

- It considers a reduction in horizontal pressures, both dynamic and pseudohydrostatic, in the part protected by an armour layer. A coefficient of reduction $(\lambda)$ is applied in the dynamic ones that depends on the armour layer's width. The pseudohydrostatic pressures have a coefficient of reduction $(\mu)$ that depends on the number of units in the armour layer. It therefore assesses the length of the rock layer. The graphs where these coefficients are obtained give values close to $0 \cdot 50$. It considers the reduction in horizontal pressures with one or two units in the armour layer, unlike the indications of Günbak-Göcke and Pedersen-Burcharth, who only consider the reduction in pressures as from three units.

- The $A_{\mathrm{u}}$ and $B_{\mathrm{u}}$ parameters necessary to calculate the run-up display incoherence in the values adopted for cubes and blocks. A lesser run-up is obtained with the values for the cube-type elements than with the block-type elements. It should be the opposite since cubes break the sheet of water less and they also shore up, presenting a smoother surface and, therefore, increasing the run-up figure. 


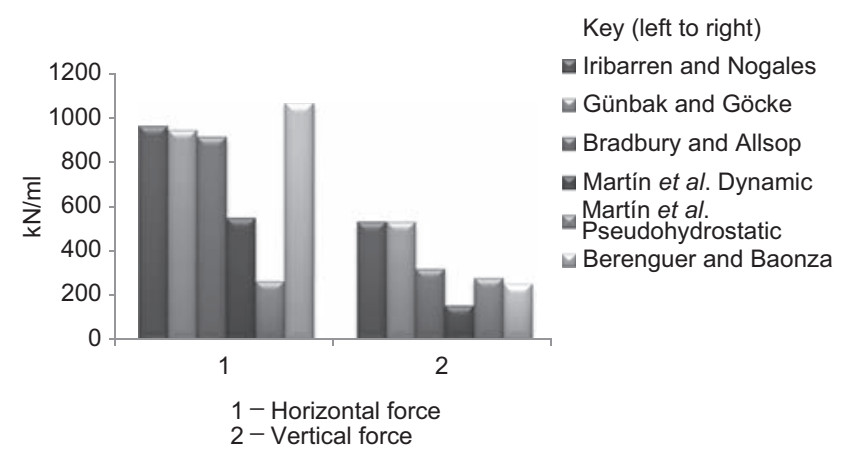

Figure 16. Mutriku new breakwater - forces

- The $\lambda$ and $\mu$ parameters are obtained for $120 \mathrm{t}$ blocks since they are calculated as from the data-taking campaign on the Príncipe de Asturias breakwater in Gijón.

- As indicated in the foregoing point, the method has been proven for the Príncipe de Asturias breakwater, which is not completely representative due to the peculiar cross-section thereof since the wave wall is built and has foundations directly on the core, formed by $90 \mathrm{t}$ blocks with a high gap index between them. It is not the classic wave wall foundation.

\subsection{Berenguer and Baonza (2006)}

- The Berenguer and Baonza (2006) method obtains horizontal and vertical pressure laws with tests with irregular waves. Using these pressures, it calculates the horizontal and vertical force as well as the moments associated with each one.

- It has been contrasted with numerous actual cases located along the whole Spanish coast.

- The waves do not break in all the tests carried out until reaching the breakwater.

- The method for calculating the forces on the wall is designed for the case of the breakwater armour layer's elements being natural rock or cubes. The run-up intervenes in this calculation with its own formulation obtained from tests with cross-sections where perforated cubes and perforated antifers are used.

- Some blocks in the armour layer were deliberately placed in the tests relating to forces on the wave wall with a certain displacement to reflect the actual state of a breakwater that has withstood storms throughout its useful life.

\section{Example structures}

The six methods related have been applied to three example structures

- Mutriku new breakwater (Guipúzcoa) (Figure 14)

- Barcelona South breakwater (Figure 15) with key

- Barcelona South breakwater (Figure 15) without key

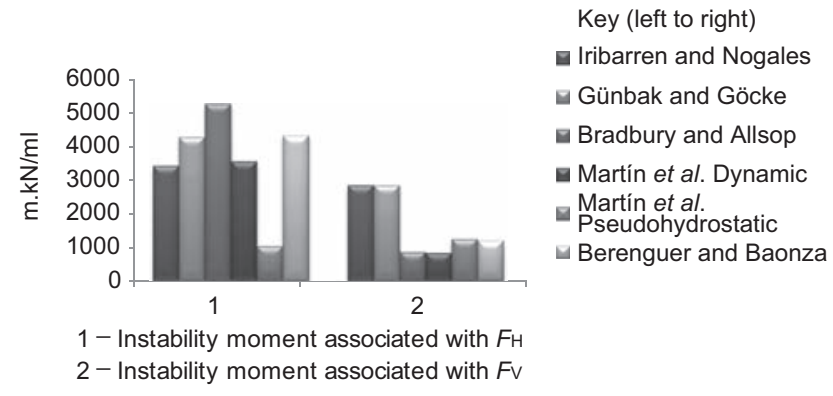

Figure 17. Mutriku new breakwater - instability moments

The case data are presented in Table 5 and results obtained are given in Tables 6 and 7. These results are also shown graphically in Figures 16 to 22 .

Results obtained show that the sections given do not fit in the sections defined by Bradbury and Allsop. Quite different results were obtained depending on the section chosen. Section A was chosen for the calculations shown in Tables 6 and 7 .

Wave actions were first calculated for each of the methods shown. Coefficients of sliding and overturn stability were calculated with the results.

In general, a high dispersion in results can be observed.

In the Mutriku example the following characteristics were observed.

- Horizontal forces have similar values in all methods except in Martín et al.'s, which gives less forces. The moment associated presents more variation depending on the method.

- Vertical forces present more dispersion than horizontal ones. Moments associated have even more dispersion.

- Iribarren and Nogales' is the most conservative method. New methods give more accurate actions because, on



Figure 18. Mutriku new breakwater - safety coefficients 


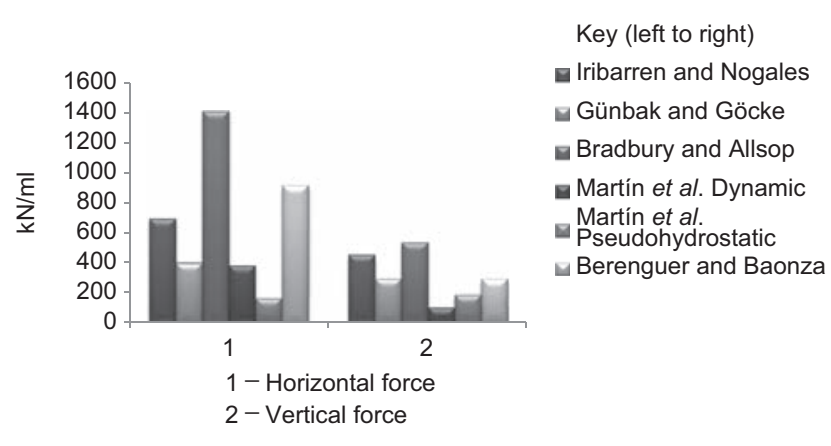

Figure 19. Barcelona South breakwater - forces

including more calculation parameters, the results are more particularised to the specific study case.

In the Barcelona South breakwater, the following characteristics can be observed.

- There is a high dispersion in horizontal and vertical forces.

- As far as the stability calculation is concerned, methods have a different sensitivity to a variation in the friction coefficient.

- Recent methods (Martín et al. and Berenguer and Baonza) do not give similar results.

\section{Proposal for a new formulation}

Methods currently used to determine wave actions on a wave wall are based on geometric and wave criteria. The existing formulations do not embody the waves' energy treatment.

This is the reason why a study is envisaged on a new formulation in which the incident waves on the wall intervene in the form of energy transmitted through the porous medium which is the armour layer, determining the diagram of pressures above the block berm in the case of run-up and the dissipated one through the units making up the slope. The first schemes used employ the

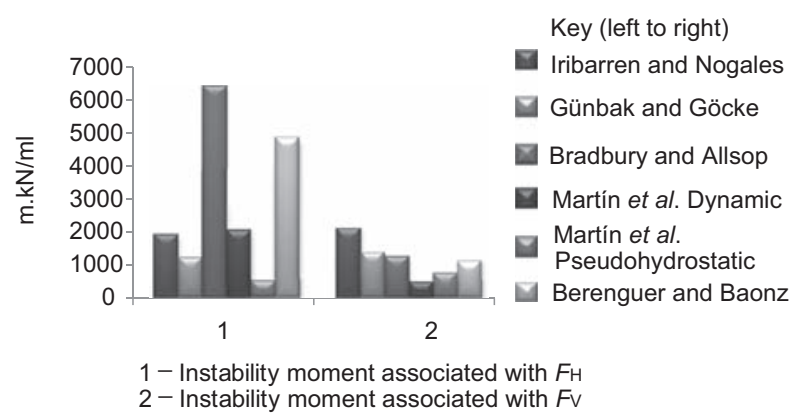

Figure 20. Barcelona South breakwater - instability moments



Figure 21. Barcelona South breakwater - safety coefficients $(\mu=0 \cdot 5)$

DELOS (Burcharth et al., 2007) formulae for transmission and run-up and pressure adjustments with rectangular laws above the berm of protection units.

\section{Conclusions}

The following conclusions may be drawn in the light of these state-of-the-art review analyses.

- All methods are based on more or less extensive laboratory tests except for Iribarren and Nogales' which, on the other hand, is very old.

- The tests on which the methods analysed are based cover a broad series of states of the sea (significant wave height, periods and so on) although the same does not apply for the geometry of the armour layer's crown, such that the slopes considered are of only two types: $1 \mathrm{~V} / 1 \cdot 5 \mathrm{H}$ or $1 \mathrm{~V} / 2 \mathrm{H}$ and the range of the number of armour layer units is limited except in Martín et al. (Table 8). This leads to the application of a method to slopes that largely diverge from those used in the tests on which those methods are based, possibly giving rise to erroneous results. The same occurs in those cases where the actual geometry cannot be fitted into that of the profile tested and the coefficients obtained therefrom (the case of Bradbury and Allsop). In such a case, reduced scale tests have to be carried out (the case of Pedersen and Burcharth), and this involves a high cost due to the formulations for

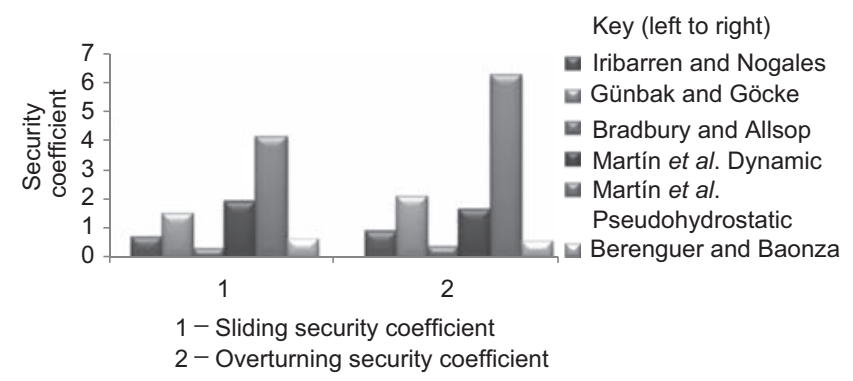

Figure 22. Barcelona South breakwater - safety coefficients $(\mu=0 \cdot 6)$ 


\begin{tabular}{|c|c|c|c|c|c|c|c|}
\hline & & $\begin{array}{l}\text { Iribarren and } \\
\text { Nogales }\end{array}$ & $\begin{array}{l}\text { Günbak- } \\
\text { Göcke }\end{array}$ & $\begin{array}{l}\text { Bradbury- } \\
\text { Allsop }\end{array}$ & $\begin{array}{l}\text { Pedersen- } \\
\text { Burcharth }\end{array}$ & $\begin{array}{l}\text { Martín } \\
\text { et al. }\end{array}$ & $\begin{array}{l}\text { Berenguer- } \\
\text { Baonza }\end{array}$ \\
\hline \multicolumn{2}{|c|}{ Year published } & 1954 & 1984 & 1988 & 1992 & 1995 & 2006 \\
\hline \multirow[t]{3}{*}{$\begin{array}{l}\text { Test based } \\
\text { on: }\end{array}$} & Waves & No & Regular & - & - & $\begin{array}{l}\text { In situ } \\
\text { measured } \\
\text { campaigns } \\
\text { (Gijón) }\end{array}$ & $\begin{array}{l}\text { Irregular } \\
\text { JONSWAP }\end{array}$ \\
\hline & Slope & No & $\begin{array}{l}\text { Run-up with } \\
5 \mathrm{~V} / 2 \mathrm{H} \\
\text { Pressures with } \\
1 \mathrm{~V} / 2 \mathrm{H}\end{array}$ & $1 \mathrm{~V} / 2 \mathrm{H}$ & $1 \mathrm{~V} / 1 \cdot 5 \mathrm{H}$ & $1 \mathrm{~V} / 1 \cdot 5 \mathrm{H}$ & $\begin{array}{l}\text { Run-up with } \\
1 \mathrm{~V} / 1 \cdot 5 \mathrm{H} \text { and } \\
1 \mathrm{~V} / 2 \mathrm{H} \\
\text { Forces with } \\
1 \mathrm{~V} / 1 \cdot 5 \mathrm{H}\end{array}$ \\
\hline & $\begin{array}{l}\text { Armour layer } \\
\text { units }\end{array}$ & No & Rock fill & $\begin{array}{l}\text { Rock fill and } \\
\text { blocks as per } \\
\text { figures }\end{array}$ & Unspecified & $\begin{array}{l}\text { Rock fill, } \\
\text { cubes, } \\
\text { tetrapods, } \\
\text { quadrapods, } \\
\text { tribar and } \\
\text { dolos }\end{array}$ & $\begin{array}{l}\text { Run-up with } \\
\text { cubes and } \\
\text { perforated } \\
\text { antifers. } \\
\text { Forces with } \\
\text { blocks and } \\
\text { rock fill }\end{array}$ \\
\hline \multicolumn{2}{|l|}{$\begin{array}{l}\text { Formulation } \\
\text { in: }\end{array}$} & $\begin{array}{l}\text { Horizontal } \\
\text { pressures }\end{array}$ & $\begin{array}{l}\text { Horizontal and } \\
\text { vertical } \\
\text { pressures }\end{array}$ & $\begin{array}{l}\text { Horizontal and } \\
\text { vertical forces }\end{array}$ & $\begin{array}{l}\text { Horizontal } \\
\text { forces }\end{array}$ & $\begin{array}{l}\text { Horizontal } \\
\text { and vertical } \\
\text { pressures }\end{array}$ & $\begin{array}{l}\text { Horizontal } \\
\text { and vertical } \\
\text { forces with } \\
\text { their } \\
\text { respective } \\
\text { moments }\end{array}$ \\
\hline \multicolumn{2}{|l|}{ Criteria } & $\begin{array}{l}\text { Geometric and } \\
\text { undulatory }\end{array}$ & $\begin{array}{l}\text { Geometric and } \\
\text { undulatory }\end{array}$ & $\begin{array}{l}\text { Geometric and } \\
\text { undulatory }\end{array}$ & $\begin{array}{l}\text { Geometric } \\
\text { and } \\
\text { undulatory }\end{array}$ & $\begin{array}{l}\text { Geometric } \\
\text { and } \\
\text { undulatory }\end{array}$ & $\begin{array}{l}\text { Geometric } \\
\text { and } \\
\text { undulatory }\end{array}$ \\
\hline \multirow{8}{*}{$\begin{array}{l}\text { Variables } \\
\text { intervening }\end{array}$} & Wave wall height & $x$ & $x$ & $x$ & $x$ & $x$ & $x$ \\
\hline & $\begin{array}{l}\text { Width of wave } \\
\text { wall foundations }\end{array}$ & $x$ & $x$ & $x$ & - & $x$ & $x$ \\
\hline & $\begin{array}{l}\text { Height of } \\
\text { emerged berm }\end{array}$ & $x$ & $x$ & $x$ & $x$ & $x$ & $x$ \\
\hline & $\begin{array}{l}\text { Width of } \\
\text { emerged berm }\end{array}$ & - & - & - & - & $\begin{array}{l}X \text { (in the } \\
\text { form of no. } \\
\text { of units) }\end{array}$ & $x$ \\
\hline & Slope angle & - & $x$ & - & - & $x$ & $x$ \\
\hline & Wave height & $x$ & $x$ & $\begin{array}{l}\text { Significant } \\
\text { wave height }\end{array}$ & $\begin{array}{l}\text { Significant } \\
\text { wave height }\end{array}$ & $x$ & $\begin{array}{l}\text { Significant } \\
\text { wave height }\end{array}$ \\
\hline & Period & - & $x$ & - & - & $x$ & $\begin{array}{l}\text { Average and } \\
\text { peak periods }\end{array}$ \\
\hline & Wave length & - & - & $\begin{array}{l}X \text { (referring to } \\
\text { the peak } \\
\text { period) }\end{array}$ & $\begin{array}{l}X \text { (referring to } \\
\text { the peak } \\
\text { period) }\end{array}$ & $x$ & $\begin{array}{l}X \text { (at foot of } \\
\text { breakwater } \\
\text { referring to } T_{\mathrm{p}} \\
\text { and } T_{\mathrm{m}} \text { ) }\end{array}$ \\
\hline
\end{tabular}

Table 8. Comparison of the methods analysed (continued 


\begin{tabular}{|c|c|c|c|c|c|c|}
\hline & $\begin{array}{l}\text { Iribarren and } \\
\text { Nogales }\end{array}$ & $\begin{array}{l}\text { Günbak- } \\
\text { Göcke }\end{array}$ & $\begin{array}{l}\text { Bradbury- } \\
\text { Allsop }\end{array}$ & $\begin{array}{l}\text { Pedersen- } \\
\text { Burcharth }\end{array}$ & $\begin{array}{l}\text { Martín } \\
\text { et al. }\end{array}$ & $\begin{array}{c}\text { Berenguer- } \\
\text { Baonza }\end{array}$ \\
\hline Year published & 1954 & 1984 & 1988 & 1992 & 1995 & 2006 \\
\hline $\begin{array}{l}\text { Wave's angle } \\
\text { of incidence } \\
\text { with the } \\
\text { perpendicular } \\
\text { to the } \\
\text { breakwater }\end{array}$ & - & - & - & - & $x$ & $x$ \\
\hline $\begin{array}{l}\text { Type of armour } \\
\text { layer units }\end{array}$ & - & - & - & - & $x$ & - \\
\hline $\begin{array}{l}\text { Armour } \\
\text { layer's } \\
\text { porosity }\end{array}$ & - & - & - & - & $x$ & - \\
\hline Others & - & - & $\begin{array}{l}\text { Predetermined } \\
\text { empirical } \\
\text { coefficients }\end{array}$ & $\begin{array}{l}\text { Empirical } \\
\text { coefficients to } \\
\text { be } \\
\text { determined in } \\
\text { each case }\end{array}$ & - & - \\
\hline
\end{tabular}

Table 8. Continued

pre-sizing the wave wall while tests allow the design to be optimised. Numerous systematic tests would need to be performed in order to increase the number of cases and obtain the adjustment parameters.

- Some methods do not offer equations for all the actions necessary to calculate the wave wall's stability (Table 8); Iribarren and Nogales do not indicate the uplift pressure distribution; Bradbury and Allsop adopt a triangular uplift pressure as an approximation from which they obtain the vertical force, but they say that a rectangular distribution on the side of safety may also be taken; and Pedersen and Burcharth only determine the horizontal force.

- In some cases, there is a lack of definition in the undulatory parameters to be used in the calculations.

- The methods do not include all characteristics in the formulations that determine the breakwater. The most complete in this aspect are those of Martín et al. and Berenguer and Baonza.

\section{Recommendations}

- The engineer must bear in mind that there is a heavy dispersion of results between methods and it is therefore advisable to use more than one method to determine results coming closer to reality.

- Studies by Camus Braña and Flores Guillén (2004) also show the dispersion of results obtained with different methods but point out that Pedersen's formulation is more reliable. In the case of being outside the range of application, good results are also obtained with this method.

- The foregoing studies (Camus Braña and Flores Guillén, 2004) also claim that a better approximation to the physical process is obtained with the method of Martín et al. because it separately analyses the dynamic and pseudohydrostatic forces.

- Some calculation methods (Iribarren and Nogales, Martín et al.) indicate their range of validity. The others do not and it is therefore understood that they are applicable in any case. Nevertheless, it is recommended to know the conditions under which the said formulations were obtained before applying them to a case far from the original parameters.

- Existing calculation methods are recommendable for prior sizing. In any event, tests on a physical model are recommended to confirm the final design. These tests may even lead to the cross-section's optimisation.

\section{REFERENCES}

Berenguer JMa and Baonza A (2006) Rubble mound breakwater crown wall design. Proceedings of the National Conference of the Port and Coastal Technical Association, Algeciras, Spain (in Spanish).

Bradbury AW and Allsop NW (1988) Hydraulic effects of breakwater crown walls. In Design of Breakwaters Proceedings of the Conference Breakwaters ' 88 . Thomas Telford, London, UK, pp. 385-396. 
Burcharth H, Hawkins SJ, Zanuttigh B and Lamberti A (2007) Environmental Design Guidelines for Low Crested Coastal Structures (DELOS Project). Elsevier, Amsterdam, the Netherlands.

Camus Braña P and Flores Guillén J (2004) Wave forces on crown walls. Evaluation of existing empirical formulations. In Coastal Engineering 2004 (McKee Smith J (ed.)). World Scientific, Singapore, vol. 4, pp. 4087-4099.

CIRIA-CUR (1991) Manual on the Use of Rock in Coastal and Shoreline Engineering. CIRIA, London, UK, CIRIA Special Publication 83/CUR Report 154.

De Waal JP, Tonjes P and van der Meer J (1996) Overtopping of sea defences. In Coastal Engineering 1996 (Edge BL (ed.)). ASCE, New York, NY, USA, pp. 2216-2229.

Goda Y (1985) Random Seas and Design of Maritime Structures. University of Tokyo Press, Tokyo, Japan.

Günbak AR and Göcke T (1984) Wave screen stability of rubble mound breakwaters. Proceedings of the International Symposium on Maritime Structures in the Mediterranean Sea, Athens, Greece, pp. 2099-2112.
Iribarren R and Nogales C (1954) Obras Maritimas: Oleaje y Diques. Editorial Dossat Madrid, Spain (in Spanish). Jensen OJ (1984) A Monograph on Rubble Mound Breakwaters. Danish Hydraulic Institute, Horsrolm, Denmark.

Losada MA (1990) Recent developments in the design of mound breakwaters. In Handbook of Coastal and Ocean Engineering (Herbich JB (ed.)). Gulf Publishing Co., Houston, TX, USA, pp. 939-1050.

Martín FL, Vidal C, Losada MA and Medina R (1995) Un método para el cálculo de las acciones del oleaje sobre los espaldones de los diques rompeolas. Ingeniería del Agua 2(3): 37-52 (in Spanish).

Negro V, Varela O, Santos J, Garcia JH and Mora JI (2008) Diseño de Diques Rompeolas. Colegio de Ingenieros de Caminos, Canales y Puertos, Madrid, Spain (in Spanish).

Pedersen J and Burcharth HF (1992) Wave forces on crown walls. In Coastal Engineering 1992 (Edge BL (ed.)). ASCE, New York, NY, USA, pp. 1489-1502.

Van der Meer J (1993) Conceptual Design of Rubble Mound Breakwaters. Delft Hydraulics Publications, Delft, the Netherlands.

\section{WHAT DO YOU THINK?}

To discuss this paper, please email up to 500 words to the editor at journals@ice.org.uk. Your contribution will be forwarded to the author(s) for a reply and, if considered appropriate by the editorial panel, will be published as discussion in a future issue of the journal.

Proceedings journals rely entirely on contributions sent in by civil engineering professionals, academics and students. Papers should be 2000-5000 words long (briefing papers should be 1000-2000 words long), with adequate illustrations and references. You can submit your paper online via www.icevirtuallibrary.com/content/journals, where you will also find detailed author guidelines. 